\title{
Violência e sexualidade: modos de construir identidades e diferenças*
}

André Luís Gomes I UnB

\begin{abstract}
Resumo: A partir de personagens marginalizadas politica e economicamente e regidas pela violência, o dramaturgo Plínio Marcos critica situaçôes patéticas da sociedade e compóe textos organicamente teatrais. Neste artigo, vamos nos ater a este renovador dos padröes dramatúrgicos, às peças Barrela e Dois perdidos numa noite suja e às respectivas versöes filmicas, para demonstrar como a violencia e a sexualidade transformam-se em modos de construir identidades e diferenças.

Palavras-chave: Teatro brasileiro, Plinio Marcos, violência, identidade, exclusão social e identidade.
\end{abstract}

\section{Introdução}

Nos últimos anos, um grande número de romancistas e contistas tem retratado não o centro, mas espaços periféricos e, em grande parte dessas narrativas contemporâneas, personagens pertencentes a grupos marginalizados

*

Este trabalho é resultado da pesquisa realizada pelo Grupo de Estudos em Dramaturgia e Crítica Teatral e conta com o apoio do Conselho Nacional de Desenvolvimento Científico e Tecnológico (CNPq) - Edital Universal. 
passaram a figurar como protagonistas. Entre tantos autores, destacamos Rubem Fonseca, Paulo Lins e Sérgio Sant'Anna. Desses autores, algumas obras podem ser citadas como exemplo: no conto "O cobrador", publicado em 1997, Rubem Fonseca expõe os pensamentos de um serial killer que comete seus crimes por acreditar que a sociedade lhe deve algo; o romance de Paulo Lins, Cidade de Deus, coloca em primeiro plano as transformações sociais pelas quais passou o conjunto habitacional Cidade de Deus, onde a criminalidade ainda pequena, nos anos 1960, cede lugar à violência generalizada e ao domínio do tráfico de drogas nos anos 1990; Sérgio Sant'Anna aborda, em O monstro, temas urbanos nos quais perversões sexuais, crimes e transgressões impulsionam os enredos com forte viés satírico e metalinguístico.

No teatro brasileiro contemporâneo, Mário Bortolotto destaca-se como o dramaturgo de personagens à margem da sociedade e é considerado o representante mais próximo do universo do autor Plínio Marcos, que, na década de 1960, colocou no palco situações cotidianas de personagens oriundas das camadas periféricas. Sobre esse renovador dos padrões dramatúrgicos e sobre a peça e a adaptação fílmica de Dois perdidos numa noite suja, vamos nos ater às tensões provocadas por um teatro pautado pela violência, pelo sexo e pela marginalidade.

\section{Entre censuras, críticas e reconhecimento: o teatro de Plínio Marcos}

A trajetória dramatúrgica de Plínio Marcos tem início em 1959, quando

Barrela teve uma única apresentação no Festival Nacional de Teatro de Estudantes, realizada em Santos, e ficou fora dos palcos devido à estupidez da censura, só voltando a ser encenada vinte anos depois, em 1980. Dez anos depois, Abajur lilás teve o mesmo destino e só foi liberada pela censura também em 1980. Nos anos seguintes a censura pró́be seus textos e o persegue. O episódio da prisão ${ }^{1}$ de Plínio Marcos causa grande impacto e marca a apresentação de Dois perdidos numa noite suja, realizada no palco do Coliseu, em Santos, no ano de 1966. Mas

1. Na crônica "Alegria é isso", publicada no jornal Última Hora, Plínio Marcos escreve sobre sua prisão, afirmando que "as autoridades não queriam de jeito nenhum deixar o meu recado ser escancarado no palco do Coliseu" (citado em CONTRERAS; MAIA; PINHEIRO. Plínio Marcos: a crônica dos que não têm voz, p. 116.) 
impacto maior teve o reconhecimento de público e da crítica especializada, como o de Alberto D'Adversa, que, entre outros, a considerou a mais inquietante e viva obra desses últimos e anêmicos anos do teatro brasileiro. Sábato Magaldi elogiou, entre outros aspectos, a originalidade do dramaturgo.

Em 1967, a crítica é convidada a assistir, no apartamento de Cacilda Becker e Walmor Chagas, Navalha na carne, ${ }^{2}$ censurada por colocar no palco, em estado bruto, três personagens regidas pela violência, impulsionadas pela agressão e submetidas a condições de miserabilidade e marginalidade. Nesse mesmo ano, foi encenada Quando as máquinas param e, no ano seguinte, Homens de papel. Setores conservadores da sociedade e da elite se colocaram contra o uso do palavrão em cena; enquanto outros, como Clarice Lispector, saiu em defesa "dos palavrões no teatro", 3 em crônica publicada no Jornal do Brasil, e elogiou a "alta qualidade" da peça. A defesa e o elogio da já consagrada escritora na época somaram-se às palavras de críticos teatrais, como Décio de Almeida Prado, Sábato Magaldi, Bárbara Heliodora e Alberto D'Aversa, que reconheciam, desde Barrela e Dois perdidos numa noite suja, a qualidade e a originalidade dos textos teatrais de Plínio Marcos.

\section{Violência e sexualidade: modos de construir identidades e diferenças}

Com Barrela, Plínio Marcos apresenta-se como dramaturgo no $2^{\circ}$ Festival do Estudante, em Santos, organizado por Pagu, Patrícia Galvão, em 1959. Barrela é, segundo o Dicionário Houaiss, a "água onde se ferve cinza e que é usada para branquear roupa" e a expressão "cair na barrela" é "ficar com a reputação

2. "A Navalha na carne dos burgueses", artigo de João Apolinário publicado no jornal Última Hora está disponível no sítio oficial de Plínio Marcos em $<$ http://www.pliniomarcos.com>. A peça Navalha na carne estreou no Teatro Maria Della Costa, em São Paulo, com Ruthnéia de Moraes, Paulo Villaça e Edgar Gurgel Aranha (substituído depois por Sérgio Mamberti), direção de Jairo Arco e Flexa. Em outubro de 1967, estréia no Teatro Maison, no Rio de Janeiro, com Tônia Carrero, Nélson Xavier e Emiliano Queiroz, sob a direção de Fauzi Arap.

3. A crônica "Dos palavrões no teatro" foi veiculada no dia 7 de outubro de 1967 no Jornal do Brasil e está publicada em LISPECTOR, Clarice. A descoberta do mundo. 
enodada, desonrar-se". As definições dicionarizadas estão metaforicamente próximas do conteúdo dessa peça em um único ato, que se passa toda em "um xadrez onde são amontoados os presos que aguardam julgamento". Um poema compõe o prólogo da primeira versão, por meio do qual se denuncia a condição dos prisioneiros que "já estão mortos", pois "já não são gente", falta-lhes esperança e vivem como fantasmas ou sonâmbulos os que "pela honra mataram ou pela fome roubaram".

Seis personagens - Bereco, Portuga, Tirica, Bahia, Fumaça e Louco dividem uma pequena cela onde são regidos pela lei da violência: um jogo tenso entre eles se estabelece e a luta pelo poder se intensifica. A identidade de cada um deles está intimamente vinculada às condições carcerárias e, especificamente, ao espaço em que dividem, no qual as relações de poder definem quem é incluído dentro desse reduzido lugar. Na condição de excluídos socialmente, os apelidos substituem os nomes, marcando quem pertence e quem não pertence a esse grupo identitário, que se constrói e impõe leis que determinam suas próprias relações sociais. O passado e o presente exercem papel fundamental na caracterização identitária, na medida em que o presente os torna comuns, o passado expõe as diferenças e constrói identidades. Se a atual condição social e material os nivela, as identidades mental e sexual servem fundamentalmente para garantir essa diferença. A sexualidade é a forma de denegrir ou enaltecer a imagem do outro e, a partir de um ponto de vista extremamente machista, transforma-se numa forma de fixar diferenças e estabelecer a hierarquização das identidades. Todos estão no "xadrez" e são, portanto, prisioneiros - essa realidade os aproxima e os coloca numa vala comum. A sexualidade passa a ser, portanto, a forma de se construir identidades: o macho, o veado, a boneca, o xerife, o corno. Bereco se impõe pela violência, é tratado por xerife e é respeitado como líder. Do Louco pouco se sabe, mas o apelido sintetiza seu comportamento pautado pela mudez e por reações que levam ao riso. O marido traído, Portuga, assassinou a esposa; a traição povoa seus pesadelos e serve para que os outros o tratem como corno. Portuga revela a todos que Tirica foi abusado sexualmente e este passa a ser o bichinha. Bahia e Fumaça querem se impor e, dentro desse sistema classificatório, ironizam e se firmam, por meio da submissão do outro e de uma visão preconceituosa, como machos. Nas últimas cenas, um jovem, Garoto, é jogado na

4. MARCOS. Melhor teatro - Plínio Marcos, p. 27. 
cela e currado, mas Tirica se afasta triste do ato violento e logo Portuga o ironiza e o acusa de brocha. Nessa disputa identitária, Portuga e Tirica se tornam inimigos e a tensão entre os dois aumenta com uma carga de suspense que redunda, no desfecho da peça, no assassinato de Portuga. Tirica aproveita a distração de Portuga em determinado momento e o esfaqueia. Nessa barrela, a origem da gratuidade do ato violento e da crueldade está num passado marcado pela miséria e pela opressão que gera opressores.

O jogo entre personagens que se revezam nos papéis de opressores e oprimidos é o centro da experiência que se repete em Dois perdidos numa noite suja. Mas, nessa peça, as seis personagens são reduzidas a duas e a cela da prisão cede lugar a um "quarto de hospedagem de última categoria, onde se vêem duas camas bem velhas, caixotes improvisando cadeiras, roupas espalhadas" (p. 64). Apesar do número de personagens se reduzir, as relações de poder e a violência se instituem da mesma forma em um locus demarcado por um universo restrito a quatro paredes.

A peça Dois Perdidos numa noite suja é dividida em dois atos, sendo que o primeiro tem quatro quadros e a cada um deles adensa-se a tensão entre Paco e Tonho. Nesse ambiente opressivo, degradante e realista, a violência se instaura como a única forma de sobrevivência, por meio de um jogo de poder no qual os dois, como peças, revezam-se:

PACO: Você tem um sapato velho, todo jogado-fora, e inveja o meu, bacana paca.

TONHO: Eu, não.

PACO: Invejoso.

TONHO: Cala essa boca!

PACO: De manhã, quando saio rápido com o meu sapato novo e você demora aí forrando sua droga com jornal velho, deve ficar cheio de bronca. TONHO: Palhaço!

PACO: (gargalha) Por isso é que você é azedo. Coitadinho! Deve ficar uma vara quando pisa num cigarro aceso. (Paco representa uma pantomima) Lá vem o trouxão, todo cheio de panca. (Ainda com pose) Daí, um cara joga a bica de cigarro, o trouxão não vê e pisa em cima. O sapato do cavalão é furado, ele queima o pé e cai da panca (Paco

5. MARCOS, Plínio. Melhor teatro - Plínio Marcos. A partir dessa citação, indicarei apenas a página do texto teatral citado. 
começa a rir e cai na cama gargalhando).

TONHO: (Bravo) Chega!

(Paco aponta a cara de Tonho e estoura de tanto rir)

TONHO: Pára com isso, Paco!

(Paco continua a rir. Tonho pula sobre ele e, com fúria, dá violentos socos na cara de Paco. Este ainda ri. Depois, perde as forças e pára; Tonbo continua batendo. Porfim, pára, cansado, ofegante, volta para sua cama. Deita-se. Depois de algum tempo, levanta a cabeça e, vendo que Paco não move, demonstra preocupação. Aproxima-se de Paco e o sacode.) (p. 71-72)

O poder de Paco está na sua capacidade de perceber e explorar a fraqueza do outro, ou seja, sua violência é exercida a partir das palavras, no jogo ardiloso para o qual sempre empurra e encurrala Tonho, manipulando-o sadicamente. Em passagens como a destacada acima, nota-se que os atos violentos de Tonho são expressos fisicamente, pois, intimamente, ele é frágil e incapaz de se perceber como peça nas mãos de Paco. Este não fala de sua origem, exerce sua maldade e ironia, adensadas com o roubo de sua flauta, afinal "ganhava grana com a flauta" da qual tirava "tudo quanto é chorinho". Tonho sonha com uma vida digna, repete insistentemente que estudou e acredita que vai arrumar um emprego, mas para isso "só precisa de um sapato". Tonho sabe que "todos pensam mal de um cara mal vestido", por isso, o par de sapatos ganha dimensão simbólica, uma vez que passa a ser considerado como possibilidade de ascensão social:

TONHO: Eu só quero um par de sapatos. Eu, às vezes, fico morto de vergonha quando na rua olho para os pés das pessoas que passam. Todos calçam um pisante legal. Só eu que uso essa porcaria toda furada. Isso me deixa na fossa... Chego até a pensar em me matar. (p. 92)

Um jogo opressivo e perverso se estabelece entre os dois. Novos elementos surgem a cada quadro do primeiro ato. Paco possui o "pisante" que Tonho precisa para conseguir emprego e essa condição favorável é utilizada para humilhar ainda mais o parceiro e acentuar sua condição de excluído. Na medida em que as fraquezas de Tonho se evidenciam, Paco vai se aproveitando desses novos elementos. No segundo quadro, invoca a figura do Negrão, "que é fogo numa briga", (p. 77) para amedrontar ainda mais o parceiro, tratado como "Boneca do Negrão" (p. 85). O tom violento, sarcástico, irônico de Paco, oprime Tonho durante todo o tempo, até que, de repente, há uma inversão, e Tonho, com um revólver na mão, assume as características do outro e o fuzila. 
Os diálogos concisos e rápidos dão tensão ao conflito estabelecido, e ao leitor/espectador são fornecidos poucos dados sobre os protagonistas. No texto, não há rubricas ou indicações detalhadas sobre aspectos físicos ou psicológicos das personagens, que determinem, por exemplo, a idade ou a cor das personagens. Por outro lado, sabe-se que Paco intimida Tonho com a história de um certo Negrão, que trabalha no mercado onde "tem muitos negrões". A partir desses comentários, pode-se intuir que Paco e Tonho são brancos, mas nada impede, a título de exemplificação, que um diretor escolha um ator negro para interpretar um deles.

No entanto, características psicológicas diferentes se evidenciam e é justamente esta habilidade, entre outras, de criar personagens tão distintas, que faz de Plínio Marcos um grande dramaturgo.

Na rubrica inicial, temos alguns detalhes sobre Paco por meio dos quais se tem um esboço de algumas de suas características psicológicas, que se completa com as atitudes da própria personagem e/ou dos comentários a respeito dela - Paco toca gaita, mas muito melhor flauta, da qual tirava certos chorinhos; orgulha-se de calçar um lindo par de sapatos em desacordo com sua roupa; é irônico, sádico, nervoso, provocador, estúpido; não tem origem, não fala sobre seu passado nem de seus familiares; é revoltado e violento e comporta-se quase até o fim da peça como o opressor, aquele que detém e se envaidece do poder que exerce sobre o outro. Paco não se revela, quase sempre define o outro - "você é muito fresco" (p. 76), "você é um cagão" (p. 79), "você é chato paca" (p. 97), "é bicha e tudo" (p. 99) - e quando se define é por meio de negações - "homem macho não tem medo de homem", (p. 78) "eu não tenho medo de negrão nenhum”, "nunca ninguém folgou com minha cara" (p. 85). Algumas dessas descrições, atitudes e silêncios de Paco, permite-nos intuir certo ressentimento que justifica, inclusive,

6. Em pesquisa realizada pelo Grupo de Estudos em Dramaturgia e Crítica Teatral, com o apoio do CNPq e sob minha coordenação, levantamos uma série de dados sobre peças teatrais contemporâneas publicadas. Ao iniciarmos estudos sobre personagens nessa dramaturgia, identificamos algumas peculiaridades do texto dramatúrgico, como por exemplo, a quase ausência de descrição de alguns aspectos físicos das personagens em poucas peças teatrais, o dramaturgo define a raça da personagem. A ausência de descrições deixa em aberto ao diretor/encenador escolher, por exemplo, intérprete com diferentes fenótipos.

7. No filme Barrela (1990), Bahia, personagem da peça, é interpretado pelo ator negro Raimundo Paixão e, no texto teatral, não há determinação da raça da personagem. 
sua revolta, frieza e afirmações secas do tipo "quem tem amigo é puta de zona" (p. 75).

Sobre Tonho não há descrições na rubrica inicial e, ao começar a cena, como pede o texto, ele afirma estar incomodado com o barulho que a gaita faz e fica nervoso, pois quer dormir. Tonho, no entanto, orgulha-se de ter estudado e de saber datilografia, sonha em encontrar um trabalho digno, mas não tem um bom sapato para procurar emprego, fala de seus parentes e é ironizado por tratálos como "papai" e "mamãe". A partir das falas de Paco é que podemos compor boa parte das características de Tonho, pois, além de defini-lo o tempo todo como "fresco", "babaca", "um cagão", aquele o amedronta e o humilha, trata-o como a "Boneca do Negrão". Tonho parece se ajustar às definições que lhe são imputadas por Paco, pois se comporta de modo amedontrado, tímido, frágil, até que, no desfecho, há uma inversão de papéis e ele adquire as características de Paco, ou seja, o oprimido transforma-se no opressor:

TONHO: Assim. Agora acabou a sua boca-dura. Vamos ver como está a sua malandragem. Cadê o dinheiro, a caneta, o isqueiro, a cinta, o relógio, o anel, o broche, a pulseira? Anda, quero tudo. Não escutou? (Paco põe tudo sobre a cama)

TONHO: Tira o sapato, vamos.

PACO: Meu...sapato...

TONHO: Passa pra cá.

(Paco tira o sapato)

TONHO: Agora vamos dividir tudo. Meio a meio.

PACO: Claro. Poxa... assim que tem que ser.

TONHO: Tudo pra mim. O brinco pra você.

(Tonbo joga o brinco em cima de Paco)

TONHO: Acabou sua malandragem. Bota essa droga na orelha!

PACO: Poxa, Tonho... Isso é sacanagem

(Tonbo encosta o revólver na testa de Paco)

TONHO: Não conversa e faz o que eu mando.

(...)

TONHO: (Frio) Vou acabar com você. Mas te dou uma chance. Prefere um tiro nos cornos ou um beliscão? Sé que o beliscão vai ser no saco com alicate. E enquanto eu aperto, você vai ter que tocar gaita.

A partir dessas personagens, Plínio transpõe para os palcos o submundo das grandes cidades brasileiras. Dessa ambientação realista, expõe as 
leis (ou a falta delas) que imperam e regem os marginalizados e excluídos da sociedade, que ainda são encontrados debaixo das pontes e nos semáforos. Sábato Magaldi recorre ao próprio dramaturgo para juntos comentarem sobre aquilo que torna Dois perdidos numa noite suja atual:

Racionalizando, hoje em dia sua criação, Plínio acredita que tenha introduzido nela aspectos sociais, que não perderam a atualidade. Basicamente está em jogo o problema da migração: os conflitos se aguçam, quando alguém se desvincula de sua cultura. (...) Segundo Plínio, Dois perdidos contém um elemento novo - a consciência de que não existe apenas uma cultura. De fato, há a erudita, a de massa, a popularesca e a popular. Cada homem fala em nome de sua própria cultura, não se entendendo com as demais.

Tonho e Paco têm, respectivamente, os rudimentos da erudita e da popular. (...) Para Plínio, a tentativa no sistema capitalista, baseado na propriedade privada dos bens sociais, é sempre no sentido massificador e não de respeitar as individualidades, tornando-se cada vez mais difícil a comunicação com o próximo. Por isso. Dois perdidos se mantém atualíssima.

Obviamente, a atualidade da peça foi um dos fatores que motivou as duas adaptações para o cinema, ${ }^{9}$ acrescentando-se que a abertura da obra às possibilidades de (re)leituras seria um outro motivo. Umberto Eco, em Obra aberta, registra a noção de pluralidade de significados - e essa abertura ou disponibilidade para as diferentes leituras e interpretações -, conforme o referencial e ponto de vista é consciente ou inconscientemente escolhido pelo leitor, pelo roteirista e pelo diretor da versão fílmica. Acrescento que essa disponibilidade da peça de Plínio Marcos para outras possíveis leituras a transforma em um sistema proponente

8. MAGALDI. Dois perdidos numa noite suja em moderna dramaturgia brasileira, p. 216.

9. Esse interesse em filmar textos teatrais não se restringe às peças de Plínio Marcos. A adaptação cinematográfica, dirigida por Anselmo Duarte, da peça teatral de Dias Gomes, O pagador de promessa, ganhou a Palma de Ouro, em Cannes, depois de menos de dois anos de sua estreia nos palcos em 1960. Em 1958, o Arena estreou a peça Eles não usam black-tie, de Gianfrancesco Guarnieri, e, vinte e dois anos depois, o filme dirigido por Leon Hirszman passa a colecionar vários prêmios. E mais o espetáculo musical Ópera do malandro, de Chico Buarque, e a versão cinematográfica de Ruy Castro em 1985. Recentemente, várias peças estrearam nos cinemas: A partilha; Ó pai ó; Trair e coçar é só começar; Cócegas. 
(nomenclatura proposta por este autor) por apresentar indícios, sutis referências e hiatos que podem ser acentuados, expandidos e reinterpretados por encenadores, e, além disso, permitir alterações, adequações, junções e apropriações.

Em 1971, o diretor Braz Chediak assina o roteiro da adaptação fílmica de Dois perdidos numa noite suja junto com os atores Emiliano Queirós e Nelson Xavier. Sem fazer concessões ao entretenimento fácil, o texto teatral é mantido quase que na íntegra, ou seja, o diálogo virulento, enxuto e seco entre Paco e Tonho está presente durante todo o filme, que centra sua ação em um quarto de hospedaria no Rio de Janeiro, divergindo da peça, que se passa em Santos. Nas sequências iniciais do filme, produzido por Jece Valadão, uma série de planos apresenta as personagens e fornecem índices da condição social dessas personagens aos espectadores. Na primeira sequência, Tonho caminha sozinho, no final da noite, pelas ruas, para na porta de um boteco e espia seus frequentadores, enquanto a voz de um menino repete manchetes de jornais: "Preso tarado da zona sul", "Ganhador da loteria" etc. Em seguida, uma sequência mostra Paco caminhando também pelas ruas, mas este entra no boteco. Com um corte, vemos trabalhadores carregarem mercadorias no porto, entre eles, Paco. Na cena seguinte Tonho está na aula de datilografia e, depois, a câmera foca seus pés num andar apressado por ruas sujas e esburacadas. Imagens de recortes de jornais - vagas de emprego - são colocadas entre a cena do andar apressado de Tonho. A câmera deixa de enquadrar só os pés, amplia o foco, e Tonho aparece com uma mala, chegando a uma hospedaria. Ali, ele é recebido por uma mulher e levado até o quarto. Ao subir a escada, ouve-se o som de alguém que toca gaita. Tonho entra no quarto onde já está Paco. A partir de então, o texto de Plínio Marcos é reproduzido quase que na íntegra, mas algumas cenas ganham locação externa, personagens ganham falas e cenas são incluídas. As inclusões reproduzem o que, às vezes, é narrado pelas personagens na peça, como por exemplo, temos, no filme, a cena do assalto ao casal de namorados.

Diferentemente dessa primeira versão, José Joffily dirige a segunda adaptação fîlmica da peça de Plínio Marcos em 2002, com roteiro de Paulo Halm. ${ }^{10}$ O roteirista faz uma série de acréscimos ao texto-fonte, incluindo novos elementos temáticos, diálogos, situações, fatos e representações sociais e suprimindo outros no filme que recebe o título de 2 perdidos numa noite suja.

10. A parceira entre José Joffily e Paulo Halm já havia sido premiada com Quem matou pixote? (1996), filme em que Halm, além de roteirista, atuou como diretor-assistente e produtor-executivo. 
O confronto entre o texto-base e o filme, tendo em vista os acréscimos e supressões, é uma forma de analisar o texto teatral, as leituras e interpretações que o roteirista e o diretor fizeram do texto original. Pode-se afirmar, antecipadamente, que o diretor e o roteirista souberam vislumbrar as propostas que estão não só nas entrelinhas, mas também explicitadas na superfície do texto teatral, ou seja, entendê-lo como um sistema proponente. Eles souberam "trair bastante o Plínio Marcos, para respeitá-lo", como afirma Paulo Halm no makinf off presente na versão em DVD do filme.

$\mathrm{O}$ ato de migrar em busca de melhores condições de vida - de uma região para outra na peça, do interior de São Paulo para Santos -, no filme, é a de um país para outro, do Brasil para os Estados Unidos. Assim, a crítica social atualizase e se acentua, pois o problema deixa de ser apenas regional e passa a ser o de uma nação que não oferece condições dignas de sobrevivência, exporta gente. Assim, um ato que deveria ser voluntário, torna-se necessário e, às vezes, única alternativa quando se procura melhorar as condições de trabalho. Dessa forma, o ato de migrar ganha uma carga de atualidade e coloca, em primeiro plano, as transformações que ocorreram nas relações de trabalho no Brasil: Tonho busca novas perspectivas de sobrevivência em Nova York, perseguindo o propagado sonho americano.

Se os problemas se aguçam, como afirma Sábato Magaldi, quando alguém se desvincula de sua cultura regional, esse aguçamento torna-se, às vezes, crítico, quando se transfere para outro país. E, no filme, o sofrimento de Tonho adensa-se, pois, além dos problemas culturais e do sentimento de fracasso já presentes no texto teatral, ele vive a angústia de estar ilegal, ser perseguido e conviver com o medo de ser deportado.

Na peça, Paco intimida e exerce seu sadismo sobre Tonho com a história de que um temido Negrão mandou avisá-lo "que vai dar tanta porrada, que é capaz de te apagar" (p. 76). Tonho entra no jogo de Paco e expõe suas fraquezas e medos, e o Negrão, personagem que não aparece em cena, agiganta-se e ganha ar fantasmagórico e diabólico. Afinal, segundo Paco, "o negão é fogo numa briga", (p. 77) "o Negrão é espeto. Briga paca", (p. 77) e Tonho se reduz, nas falas de Paco, a uma "Boneca do Negrão". Ao se deixar levar pelo jogo estabelecido, essa figura tenebrosa passa a persegui-lo, a ser uma ameaça, transformando-se numa possibilidade até de morte.

Em 2 perdidos numa noite suja, não é por meio desse "Negrão" que Paco passa a exercer poder sobre Tonho, pois esse símbolo de opressão ganha outros correspondentes: presidiários negros, a Polícia Federal e a própria 
prisão. Nas primeiras cenas do filme, em que Tonho está na prisão, há uma sequência de planos separados por cortes bruscos: foco em Tonho, que faz exercícios em uma academia - corte - Tonho sentado sozinho no refeitório enquanto é observado por outros presidiários - corte - Tonho tomando banho - corte - câmera acompanha os passos de dois homens que se aproximam - corte - foco no rosto assustado de Tonho - corte - plano-detalhe numa mão negra que fecha o registro do chuveiro - corte - plano-detalhe no chuveiro que pinga as últimas gotas - corte - por fusão-plano em Tonho no chão sozinho em postura embrionária - corte - câmera passeia pelo corpo de Tonho mostrando hematomas - corte - plano-detalhe em Tonho, sentado e escrevendo uma carta para sua mãe, enquanto o espectador ouve o conteúdo desta em voz over. Ruídos e uma sonoplastia saturam a tensão e o clima pressentidos.

Essa sequência na prisão fornece várias informações sobre Tonho, que também estão na peça, afinal ele se sente sozinho, é tímido, medroso, mas acrescenta-se o fato de ele já ter sido preso e estuprado por presidiários.

As possibilidades de Paco exercer seu sadismo sobre Tonho, portanto, são facilitadas por um passado que sempre se presentifica na mente de Tonho e que Paco faz questão de lembrar. Afinal, Tonho aprendeu a ter medo, foi perseguido, violado na sua liberdade e violentado.

A onipotente presença ameaçadora do Negrão, na peça, é evocada por Paco, que, no filme, busca no passado de Tonho não só o "Negrão", mas outros elementos como uma forma de transformar o presente sempre ameaçador: estar ilegal, ser descoberto pela "migra", ser preso novamente e deportado. Tonho não é abordado por policiais, mas vê homens que entram no local onde mora, assiste a Paco conversando com eles e o mesmo afirma que são mesmo a "Migra" que está atrás dele.

Ao compor a dramaturgia fílmica, Paulo Halm e José Joffily parecem seguir o que Peter Brook assevera em Porta aberta:

O ator e o diretor têm que seguir o mesmo processo do autor, ou seja, saber que cada palavra, por mais ingênua que pareça, não é inocente. Contém em si mesma, bem como no silêncio que vem antes e depois, toda uma complexidade oculta de energias entre as personagens. ${ }^{11}$

11. BROOK. Anatomia e divergência em Barrela, de Plínio Marcos, p. 9. 
E Plínio Marcos deixa a personagem Paco em uma certa obscuridade e oculta descrições a respeito dele. Nas rubricas, tanto nas falas de Tonho quanto nas de Paco, há muito pouco sobre este. Como apontamos anteriormente, não há informações sobre quem ele é, de onde veio, mas há indicações de seu orgulho e vaidade quando, em rubrica, o dramaturgo informa que ele calça "um lindo par de sapatos". Além de tocar gaita, ele toca flauta muito melhor, ou seja, atrás de toda uma postura sádica e fria, há interesse pela música, pelo chorinho e, portanto, certa sensibilidade.

O ocultamento de alguns traços, as descrições e atitudes que desvelam um pouco das características de Paco levaram os adaptadores a transformar Paco em Rita, ${ }^{12}$ que se traveste de homem. Entre as transformações, alterações e adequações contextuais realizadas nesta adaptação para o cinema, certamente, a que causou mais polêmica foi, sem dúvida, essa transformação.

O tema da homossexualidade masculina está o tempo todo presente na peça, mas é tratado de forma preconceituosa e estereotipada, pois a condição homossexual de Tonho é uma possibilidade e serve para que Paco o ironize e o agrida. No filme, o modo de apresentar e discutir a homossexualidade masculina sofre poucas alterações, mas se adensa, uma vez que cenas sugerem que Tonho tenha sido violentado na prisão.

Entretanto, o tema do travestismo lança um novo olhar sobre a temática da homossexualidade presente no texto-base, afinal Rita se traveste de Paco e se recusa a ser tratada pelo nome de batismo. Os estereótipos continuam presentes, mas, ao lado de Tonho, que se sente humilhado, temos Paco, que se orgulha.

No filme, Paco não toca flauta, ele compõe músicas, canta e sonha em ser uma estrela do rap. Compra um "pisante novo" digno de um pop star. E entre os dois se estabelece o paralelo conflituoso de desejos distintos: Tonho sonha em voltar para o Brasil; Paco, em ser um grande estrela. Quando comparados, os desejos de cada um reforçam a humildade de Tonho e a vaidade e prepotência de Paco. Essas diferenças acentuam a tensão conflituosa e o jogo entre o opressor e oprimido, tanto na peça como em 2 perdidos numa noite suja.

12. Débora Falabella interpreta Paco e Roberto Bontempo, Tonho. Pelo seu desempenho, a jovem estrela global ganhou o prêmio de melhor atriz no Festival de Brasília do Cinema Brasileiro e no Grande Prêmio Cinema Brasil. O filme acumula outros prêmios, como o de melhor direção, melhor trilha sonora em diferentes festivais. Outras informações estão disponíveis em: <http://www.doisperdidos.com.br/doisperdidos/pub/index.htm>. 
Presente no texto-base, esse confronto e esse jogo se mantêm e ganham outros elementos no filme: Paco sabe inglês muito bem, é um artista, consegue juntar dinheiro se prostituindo, não foi preso, não está na condicional, cheira cocaína, não foge da "Migra", seduz Paco e se orgulha de seu travestismo, enquanto Tonho não sabe inglês muito bem, não tem grandes ambições, está ilegal, já foi preso, é contra drogas, tem medo da "Migra" e é, a todo tempo, tratado pejorativamente de "veado".

O embate entre posturas tão contraditórias cresce com força violenta e opressiva, que resulta num desfecho inesperado e surpreendente. Na peça, a ideia de assaltar casais de namorados é exposta, mas não temos a cena desse assalto. No início do segundo ato, tem-se a seguinte rubrica: "Pano abre, vão entrando Tonho e Paco. O primeiro traz um par de sapatos da mãe e, nos bolsos as bugingagas roubadas. Está bastante nervoso. Paco traz um porrete na mão e está alegre.”

A partir das descrições que estão na rubrica e do desenvolvimento do diálogo, o espectador fica sabendo que o assalto já ocorreu no hiato entre o primeiro e o segundo ato.

No filme, a rubrica é desdobrada em várias cenas, pois eles assaltam um dos clientes de Paco, uma "bicha velha". Paco, movido e cegado pela ação violenta, mata o velho, enquanto Tonho, nervoso, discorda das atitudes violentas de Paco e do desfecho trágico. No filme, os dois também entram o quarto, distribuem os objetos e o dinheiro roubados no chão para dividir a "moamba" que conseguiram, como na peça:

PACO: Metade da grana pra cada um. Relógio, isqueiro, caneta e carteira, pra mim. Pulseira, anel, broche e cinta, pra você. Topa? TONHO: O brinco, pra você, o sapato, pra mim.

PACO: Não! O brinco, pra você, outro, pra mim. Um pé de sapato, pra você, outro, pra mim.

TONHO: O sapato é meu.

PACO: Um pé pra cada um.

TONHO: Não seja burro. O que é que eu vou fazer com um pé de sapato.

PACO: Não sei, nem quero saber.

TONHO: O sapato é meu. Eu já falei mais de mil vezes. Eu só entrei nesse assalto por causa dele e vou ficar com ele.

PACO: Então, o resto é meu.

TONHO: O resto meio a meio. 
PACO: Aqui pra você! (Faz gesto) Ninguém me leva no tapa. (pausa) TONHO: Está bem, Paco. Fique com tudo. Você me levou no bico, mas não faz mal. (p. 121)

Na peça, depois de abdicar de tudo, Tonho descobre que o sapato não lhe serve, ou seja, não lhe sobrou nem mesmo a possibilidade de arrumar um emprego. Por sua vez, o sentido de trabalho, ainda que esteja vinculado à sobrevivência individual e familiar, ultrapassou as fronteiras da necessidade material e o par de sapatos passou a significar um meio pelo qual ele pode expressar e afirmar sua identidade. Sem os sapatos, Tonho, portanto, desespera-se, e esse desespero é aguçado pelas ironias de Paco.

No filme, Paco quer levar a melhor, argumentando que foi ele que "apagou" o cara e, por isso, conseguiram o dinheiro. Paco utiliza-se o tempo todo da fragilidade de Tonho. Não quer deixá-lo nem mesmo com dinheiro suficiente para voltar ao Brasil e o ameaça, firmando que pode lhe atribuir o assassinato, afinal ele já tem ficha na polícia. O par de sapatos é substituído, no filme, pelos objetos e pelo dinheiro, ou seja, pela posse do capital, um meio de promover socialização. Pressionado e sem saída, Tonho pega sua arma, vira o jogo, uma vez que passa a ameaçar e humilhar Paco e sai com boa parte do que roubaram. Tonho mata Paco, metaforicamente, ao exigir que Rita fique nua. Desnudar Rita é revelar sua verdadeira identidade, é desnudá-la de seu saber, de seu talento, de sua forma de sobrevivência e de seu orgulho.

Enquanto na peça Tonho fuzila Paco e nele se converte, afirmando, aos gritos, que é mau e se autodenominando Tonho maluco; no filme, Tonho mata Paco, na medida em que despe Rita e expõe, enfim, sua fragilidade e verdadeira identidade. Tonho deixa o quarto, ganha as ruas; mas, diferentemente do textobase, não se transforma no opressor, pelo contrário, sai carregando os objetos roubados e o "pisante" de Paco, numa atitude que potencializa seu sentimentalismo - afinal ele confessa entre lágrimas, enquanto desnuda Paco, amar Rita. E, na longa sequência final, Tonho caminha ao som da música-tema do filme, composta por Arnaldo Antunes, numa espécie de clip.

A adaptação filmica cumpre o papel de trair o texto-base, mas também o respeita, principalmente por manter a ideia original de Plínio Marcos de escancarar, como voz legítima, a degradante condição social dos marginalizados e denunciar as consequências de uma sociedade excludente. Entretanto, não reproduz a denúncia de Plínio de que a opressão gera opressores. 
Abstract: Through characters that are marginalized politically and economically and governed by the violence; the playwright Plinio Marcos criticizes pathetic situations of the society and composes texts organically theatrical. We are going to keep to this renovator of the theatric standards, to the pieces Barrela and Dois perdidos numa noite suja and to their respective versions filmicas to demonstrate how the violence and the sexuality are turned into ways of building identities and differences

Keywords: Brazilian theater, Plinio Marcos, violence, social exclusion and identity..

$$
\text { Referências }
$$

BAKTHIN, Mikhail. Questões de literatura e de estética: a teoria do romance. 4. ed. São Paulo: Ed. Unesp, 1998.

BONASSI, Fernando. Plínio Marcos está morto. Viva Plínio Marcos! Rodapé- Crítica de Literatura Brasileira Contemporânea. São Paulo: Nankin, n. 1, p. 179-181, 2001.

BORNHEIM, Gerd A. Teatro e Literatura. In: Teatro: a cena dividida. Porto Alegre: L\&PM, 1983. p. 73-90.

BRANCO, Lucio Allemand. Anatomia e divergência em Barrela, de Plínio Marcos. Revista de Estudos de Literatura Brasileira Contemporânea, Brasília: TEL/UNB, n. 25, p. 37-55, jan.-jun. 2005.

BROOK, Peter. A porta aberta: reflexões sobre a interpretação e o teatro. Rio de Janeiro: Civilização Brasileira, 2002.

CARVALHAL, Tânia Franco. Literatura Comparada: a estratégia interdisciplinar. Revista Brasileira de Literatura Comparada. Abralic, Niterói, 1991.

CONTRERAS, Javier Arancibia; MAIA, Fred; PINHEIRO, Vinícius. Plínio Marcos: a crônica dos que não têm voz. São Paulo: Boitempo Editorial, 2002.

ECO, Umberto. A estrutura ausente. São Paulo: Perspectiva, 1991.

ECO, Umberto. Obra aberta. 8. ed. São Paulo: Perspectiva, 2001.

FARACO, Carlos A. Linguagem e diálogo: as idéias lingüísticas do círculo de Bakhtin. 2. ed. Curitiba: Criar. 2006. p. 65.

GOMES, André Luís. Clarice em Cena: as relações entre Clarice Lispector e o Teatro. Brasília: Editora Universidade de Brasília: Finatec, 2007.

LANYI, José Paulo. Plínio Marcos. O andarilho da corda bamba. Cult: Revista Brasileira de Literatura, ano III, n. 27, p. 12-19.

LISPECTOR, Clarice. Dos palavrões no teatro. In: Descoberta do mundo. Rio de Janeiro: Nova Fronteira, 1984. p. 30

MAGALDI, Sábato. Dois perdidos numa noite suja em moderna dramaturgia brasileira. São Paulo: Perspectiva, 1998. p. 215-221. 
MARCOS, Plínio. Melhor teatro - Plinio Marcos. (Seleção e Prefácio de Ilka Marinho Zanotto). São Paulo: Global, 2003. [Coleção Melhor Teatro]

MARTINS, Gilberto. De pisantes e pisados - representações da falta (Percursos intertextuais e interdiscursivos com Alberto Moraiva e Plínio Marcos. In: CAIRO, Luiz Roberto et al. (Org.). Nas malhas da narratividade: ensaios sobre literatura, história, teatro e cinema. Assis: FCL/Unesp - Publicações, 2007.

VIEIRA, Paulo. Plínio Marcos: a flor e o mal. Petrópolis: Firmo, 1994.

A vingança do maldito. Revista Cultura Vozes. Petrópolis: Vozes, Ano 89, n. 4, p. 112-125, jul-ago. 1995.

XAVIER, Ismail. Do texto ao filme: a trama, a cena e a construção do olhar no cinema. In: PELLEGRINI, Tânia et al. Literatura, cinema e televisão. São Paulo: SENAC/ Itaú Cultural, 2003. p. 61-90. 